\title{
Chapter 20 \\ Diaspora Policies, Consular Services and Social Protection for Maltese Citizens Abroad
}

\author{
Hillary Briffa and Alessandra Baldacchino
}

\subsection{Diaspora Characteristics and Home Country Engagement}

This chapter assesses the social protection policies enacted by Malta to support the needs of Maltese living abroad. First, the current status of the Maltese diaspora and their engagement with the homeland is contextualized, and key infrastructure and policies outlined. Thereafter, in line with the focus of this book, five areas of concern are addressed: unemployment, healthcare, pensions, family-related benefits, and economic hardship.

Malta is shown to have strong relations with host countries of Maltese emigrants, and there are ongoing communication initiatives between the Maltese government and its citizens abroad; however, this chapter recognises that there is still a long way to go in terms of ensuring democratic participation of citizens in elections. The evidence has been compiled primarily as a result of consultation with primary source material, including national legislation and international treaties, and interviews with a range of experts within relevant Maltese governmental bodies. ${ }^{1}$ The chapter reflects policies in place as of March 2019.

\footnotetext{
${ }^{1}$ Gratitude is expressed in particular to Ms Marie Das Mifsud (Senior Principal Officer, International Relations Unit), Mr. Joseph Xerri (Secretary, Council for Maltese Living Abroad), Dr. Raymond Xerri (Director, Directorate for Maltese Living Abroad), Ms. Rachel Galea (International Affairs Officer, Ministry for the Family, Children's Rights and Social Solidarity), Ms. Eugenie Megally (Second Secretary, DG Political, EU Affairs, Maltese Abroad), Mr. Julian Zarb (Cultural Diplomacy Unit, Ministry for Foreign Affairs and Trade Promotion), Ms. Christine Said (Consul, Second Secretary, Malta High Commission to the United Kingdom), Kailyze Attard (Executive EU Affairs at Jobsplus), Dr. Antoinette Cutajar (Directorate for Maltese Living Abroad), and Mrs. Rosalie
}

H. Briffa $(\bowtie) \cdot A$. Baldacchino

King's College London, London, UK

e-mail: hillary.briffa@kcl.ac.uk 


\subsubsection{The Maltese Diaspora and Its Relationship with the Homeland}

After the Second World War, Malta experienced mass emigration as a result of difficult economic conditions, combined with the post-war baby boom. During this period, Malta's Emigration Department assisted emigrants in bearing the financial cost of relocation and between 1948 and 1967, 30\% of the population left the island (Jones 1973). Between 1946 and the late 1970s, more than 140,000 Maltese citizens emigrated on the assisted passage scheme, with 57.6\% settling if Australia, 22\% in the United Kingdom (UK), 13\% in Canada and 7\% in the United States of America (US) (Attard 1989). Emigration slowed after the 1970s, but to this day Maltese individuals still seek opportunity beyond their island shores.

Today, the concentrations of Maltese living abroad largely reflect the post-war mass exodus. According to the 2011 Census, there were 163,990 people of Maltese descent living in Australia, the largest community of which could be found in the state of Victoria (19,730 people). ${ }^{2}$ In Canada, 38,780 Canadians were recorded as claiming Maltese ancestry. ${ }^{3}$ The Maltese communities are largely concentrated in Ontario, but may also be found in Montreal, Vancouver, Winnipeg, and St. John's. Meanwhile, as a result of its colonial history, it is little wonder that the UK and Malta were frequent hosts for each other's emigrants. In 1942, General William Dobbie set up The Malta League (active until 2010) to engender communication between the many Maltese in London. In 2009, there were approximately 28,000 Maltese-born residents in the UK. ${ }^{4}$ Further afield, in 2016 there were 40,820 Americans of Maltese ancestry (24,202 of whom have Maltese as their first ancestry). ${ }^{5}$

The strength of historic ties with the destination countries of Maltese emigrants is mainly reflected in the number of Reciprocal Agreements signed between Malta and partner countries. Reciprocal Agreements are formal treaties that help coordinate the social security systems of the respective contracting countries. ${ }^{6}$ Malta and the UK, for instance, have a close relationship; the Malta High Commission to the

Rivett (President of The Malta Diaspora UK, and former chair of The Malta League between 1990 and 2010).

${ }^{2}$ Census 20,680 - Country of Birth of Person by Sex - Australia. (2011). The Australia Bureau of Statistics. http://www.censusdata.abs.gov.au. Accessed 31 March 2019.

${ }^{3}$ Ethnocultural Portrait of Canada. (2006) Statistics Canada. http://www12.statcan.ca/censusrecensement $/ 2006 /$ dp-pd/hlt $/ 97-562 /$ pages $/$ page.cfm $?$ Lang $=E \& G e o=P R \&$ Code $=01 \&$ Table $=2 \& D$ ata $=$ Count $\&$ StartRec $=1 \&$ Sort=3\&Display=All. Accessed 31 March 2019.

${ }^{4}$ Estimated population resident in the United Kingdom, by foreign country of birth (Table 1.3). (2009, September). Office for National Statistics UK. http://www.statistics.gov.uk/downloads/ theme_population/Population-by-country-of-birth-and-nationality-Oct08-Sep09.zip. Accessed 31 March 2019.

${ }^{5}$ American Community Survey 1-year Data. (2016). United States Census Bureau.

${ }^{6}$ Bilateral Conventions on Social Security. Department of Social Security. https://socialsecurity. gov.mt/en/International-Affairs/Pages/Other-Conventions.aspx. Accessed 31 March 2019. 
UK is located in London, however Malta also maintains consulates in Belfast, Cardiff, Edinburgh, and the Isle of Man. As of 2017, there were estimated to be 31,000 Maltese citizens resident in the UK, and a further 1,000 Maltese students attending universities in Britain (Sansone 2017). The strong ties between the two countries are visible in their exchange of reciprocal benefits in the areas of health, social security, cooperation and mutual support (Saliba Haig 2016).

Although a Reciprocal Agreement for social security has not yet been signed between Malta and Italy, the Embassy of Malta in Rome was amongst the country's first embassies established overseas, inaugurated in 1967. Geographical proximity and intense cultural, historical and personal ties continue to facilitate the enhancement of the wide spectrum of relations as reflected in Italo-Maltese political, economic, and cultural cooperation. ${ }^{7}$ Maltese consulates in Italy may be found in Barletta, Bologna, Cagliari, Catania, Florence, Genoa, Milan, Syracuse, Trieste, and Venice.

Most recently, an increasingly significant number of Maltese have emigrated to Europe in the wake of Malta joining the European Union (EU) in 2004. By 2010, this number was estimated at 500 emigrants (Cauchi 2016). Belgium and Luxembourg have seen a surge in Maltese arrivals, pursuing employment opportunities with the European institutions.

\subsubsection{Diaspora Infrastructure}

Malta's law on consular functions (Cap 144) pre-dates the Vienna Convention on Consular Relations. Hence, in the Maltese legal system, there is no domestic law granting the right to consular or diplomatic protection. Malta has, however, incorporated the substantive provisions of the Vienna Convention on Diplomatic Relations through the Diplomatic Privileges and Immunities Act 1966 (Cap 191). Therefore, consular assistance is indeed offered as a matter of practice and policy on the basis of respect for fundamental rights of the individual, which are enshrined in the Maltese legal system (CARE 2010). To fulfil this function, a number of bodies under the umbrella of the Maltese Ministry for Foreign Affairs and Trade Promotion (MFTP) regulate Maltese diaspora policy. Engagement with diaspora is arguably a key priority for Malta as the national security document 'Malta's Foreign Policy: Guiding Principles' (2013) outlines the government's commitment to 'ensure regular and closer consultation with Maltese communities abroad; promote stronger political and economic relations with the countries of Maltese migration; encourage the involvement of the Maltese Living Abroad in complementing efforts to promote Malta, particularly its commercial and business facilities in the respective countries

\footnotetext{
${ }^{7}$ Embassy of Malta in Italy.https://foreignaffairs.gov.mt/en/Embassies/Italy/Pages/ME_Rome. aspx. Accessed 31 March 2019.
} 
of Maltese migration; support and facilitate the work and activities of the Council for Maltese Living Abroad'. 8

The needs of the Maltese diaspora predominantly fall under the remit of the Directorate for Maltese Living Abroad within the Directorate-General for Political, EU Affairs and Maltese Abroad, which forms part of the structure of MFTP. Malta has a track record of maintaining contact with its diaspora and held its first Convention for Maltese Living Abroad in 1969; others followed in 2000, 2010, and 2015 (Xerri 2015). The main duties of the MFTP Directorate for Maltese Living Abroad are to serve as a focal point of information for policy-making related to diaspora issues; to keep regular contact with stakeholders related to the Maltese living abroad; to monitor local legislations and EU regulations potentially affecting Maltese living abroad; to provide consultation and advice to the government on diaspora matters; to maintain close and effective liaison with Malta's overseas diplomatic missions; to keep close contact and assist the Secretary of the Council of Maltese Living Abroad (CMLA); to ensure the implementation of decisions made by the CMLA; to assist in the preparation for the Convention for the Maltese Living Abroad; to maintain a register of NGOs and Associations of the Maltese living abroad; and to promote and encourage the voluntary registration of Maltese citizens living abroad. ${ }^{9}$

The Conventions are arguably more than just a talking shop or publicity exercise as they have borne concrete results. As a result of the 2010 Convention, the Maltese government committed to establishing a public institution to safeguard the interests of the Maltese living abroad and then Minister of Foreign Affairs, Dr. Tonio Borg, expressed his intention to give this institution a legal basis through the enactment of a Bill in Parliament. ${ }^{10}$ Hence, in 2011 a new law was passed to amend the Constitution of Malta by adding a new article, 20A, which expressly states that 'the State shall facilitate the participation of Maltese citizens who live abroad in the political, social, economic and cultural life of Malta'. ${ }^{11}$ The 'Council for Maltese Living Abroad Act, 2011' (Act No. XX of 2011) further sought to establish a Council for Maltese Living Abroad, tasked with protecting and promoting the rights and interests of Maltese living abroad. ${ }^{12}$ The CMLA is chaired by the Minister of Foreign Affairs and made

\footnotetext{
${ }^{8}$ Malta's Foreign Policy: Guiding Principles. Ministry for Foreign Affairs and Trade Promotion. https://foreignaffairs.gov.mt/en/Documents/GuidingPrinciples.pdf. Accessed 31 March 2019.

${ }^{9}$ Directorate General Political, EU Affairs and Maltese Abroad. Ministry for Foreign Affairs and Trade Promotion. https://foreignaffairs.gov.mt/en/Pages/DG-Political.aspx. Accessed 31 March 2019.

${ }^{10}$ Establishing a Council for Maltese Living Abroad. (2011). Maltese Community Council of Victoria, Inc. https://www.mccv.org.au/establishing-a-council-for-maltese-living-abroad/. Accessed 29 April 2019

${ }^{11}$ Constitution of Malta (1964). Ministry of Justice, Culture and Local Government. Valletta. http:// justiceservices.gov.mt/downloaddocument.aspx?app=lom\&itemid=8566. Accessed 31 March 2019.

${ }^{12}$ Council for Maltese Living Abroad Act, Act No. XX of 2011. Ministry of Justice and Home Affairs. http://www.ilo.org/dyn/natlex/natlex4.detail?p_lang=\&p_isn=90485. Accessed 31 March 2019.
} 
up of a group of persons living abroad, selected by the Prime Minister. Objectives include promoting the quality of life of the Maltese communities abroad; strengthening political, cultural, economic and social ties between the Maltese communities abroad and Malta; promoting and facilitating the preservation of a cultural and linguistic identity among the community; analysing problems which Maltese communities encounter (including issues relating to working conditions, professional and educational training, and recognition of qualifications obtained by Malta); and advising the Minister of Foreign Affairs on any legislation or issue that can affect the interests of Maltese abroad.

The Council convenes once a year in Malta, following a year of internal consultations among councillors and externally with the communities that they represent around the globe. The outcome of the Council meetings serves as the basis upon which the Directorate for Maltese Living Abroad within MFTP works, in conjunction with line ministries and government agencies, to implement the proposals of the Maltese diaspora. Items of discussion in the past have included the teaching of the Maltese language and the history of Maltese emigration, the dissemination of Maltese culture, the effects of property laws and taxation rates on Maltese living abroad, dual citizenship, distance voting in European Parliamentary elections, and establishing a register for diaspora organisations and prominent Maltese living abroad. During the ninth meeting of the Council, held in 2018, then Foreign Minister Carmelo Abela raised the possibility of establishing regional committees so that a greater number of Maltese living abroad may have the opportunity to participate actively in initiatives relating to the Maltese diaspora. ${ }^{13}$ This may therefore be enacted in the near future.

Currently, ${ }^{14}$ Malta maintains 24 embassies and high commissions abroad, as well as 190 consulates and one other representation. ${ }^{15}$ The Consular Services Directorate within MFTP deals directly with services aimed at the general public. The Maltese diplomatic staff serving abroad enable the Directorate to provide a broad array of services to Maltese individuals, ranging from medical assistance to assistance to victims of crime, and loss or theft of travel documents. In such situations, the Directorate acts as the point of contact between the individual and his or her family, facilitates financial transactions when needed and, in countries where Malta has a diplomatic presence, ensures that Maltese diplomatic agents, whenever possible, visit and assist the person in distress. The Directorate also helps in searching for

\footnotetext{
${ }^{13}$ Government continues strengthening relation with Maltese living abroad. (2017, October 13).

The Malta Independent. http://www.independent.com.mt/articles/2017-10-13/local-news/ Government-continues-strengthening-relation-with-Maltese-living-abroad-6736180198. Accessed 31 March 2019.

${ }^{14}$ This information is correct as of 28 March 2019. Malta's Embassy in Tripoli has been temporarily closed since 2014 as a result of Libya's domestic crisis but a new Ambassador is due to take up residency in the near future.

${ }^{15}$ Representative Office of Malta in Ramallah, Palestine.
} 
Maltese citizens reported missing while abroad and provides information to the family. ${ }^{16}$

The Directorate provides general information concerning visa procedures for Maltese nationals wishing to travel abroad. Regularly updated travel advice is additionally provided to Maltese nationals who may need to travel to countries where the political situation may not be conducive for travel. Whenever a country or region is affected by an emergency or crisis situation, the Directorate serves as the point of contact between Maltese nationals abroad and their concerned families at home by setting up an ad hoc Emergency Crisis Centre. ${ }^{17}$

It was anticipated that Malta's accession to the EU in 2004 would increase the demands of administering obligations in the social security field. Therefore, the Ministry for the Family, Children's Rights and Social Solidarity established an International Relations Unit (IRU) in 2003. The international scope of the Department of Social Security (DSS) goes beyond the EU, however, and the IRU therefore contends with a broader range of international concerns. Indeed, the IRU has become a fully-fledged unit dealing with all benefits under all bilateral agreements, international agreements and covenants which the DSS has entered into, as well as EU Regulations (EC) Nos. 883/2004 and 987/2009 on the coordination of social security systems. ${ }^{18}$ The Unit attends meetings both locally and abroad regarding social security, including the Administrative Commission on Social Security for Migrant Workers, the Ad Hoc Working Group on electronic data exchange, the Social Questions Working Party, Mutual Information System on Social Protection, and other Council of Europe conferences. ${ }^{19}$

\subsubsection{Key Engagement Policies}

Malta demonstrably has infrastructure in place specifically targeted to the needs of its citizens abroad, and through the Directorate for Maltese Living Abroad (MFTP) and the IRU a range of engagement policies have been put into place.

The Ministry for Foreign Affairs runs a voluntary notification service for Maltese citizens living abroad. All Maltese citizens who intend to travel or live abroad for over a month, whether temporarily or permanently, are urged by the government of Malta to fill in and sign a form called 'Notification D'. ${ }^{20}$ This allows the government

\footnotetext{
${ }^{16}$ Directorate for Consular Services. Ministry for Foreign Affairs and Trade Promotion. https:// foreignaffairs.gov.mt/en/Pages/Directorate-for-Consular-Services.aspx. Accessed 31 March 2019.

${ }^{17} \mathrm{Ibid}$.

${ }^{18}$ International Relations Unit. Department of Social Security. https://socialsecurity.gov.mt/en/ International-Affairs/Pages/default.aspx. Accessed 31 March 2019.

${ }^{19} \mathrm{Ibid}$.

${ }^{20}$ Voluntary Registration for Maltese Travelling and Living Abroad (Notification D). Government services. https://servizz.gov.mt/en/Pages/Other/Foreign-Affairs/Maltese-Communities-Abroad/ WEB010/default.aspx. Accessed 31 March 2019.
} 
to provide better protection and assistance to nationals living abroad through its consulates.

Every legal process that involves Maltese and foreign jurisdictions may seek assistance of the Consular Services Directorate which, through its network of embassies and consulates abroad, serves as the main point of contact between the juridical authorities of the countries concerned. The Directorate has a Legalisation Unit which issues so-called Apostilles or Legalisation certificates. Whenever a Maltese national is arrested or sentenced by a foreign court, MFTP acts as the means of communication between the detained individual and the family in Malta and tries to ensure that the convicted citizen has access to adequate legal representation, in a language that s/he may understand.

New Maltese passports are biometric and must be issued by the Passport Office in Malta. Hence, applicants must submit their application in person at the consulate, where their biometric data is captured electronically and subsequently transmitted to the Passport Office in Malta for processing. ${ }^{21}$ To address accessibility issues, the Maltese government set up the 'Consul-on-the-Move' in 2016, a programme which provides some consular services ordinarily available at Maltese embassies, high commissions and consulates general abroad. Services offered through this initiative include applications for life events certificates and Maltese citizenship. The programme arguably conforms with the government's policy to bring its services closer to the citizens. ${ }^{22}$ Currently, the service is available in the top five destination countries for Maltese abroad: Canada, the US, the UK, Australia and New Zealand.

In countries where there is no formal embassy, high commission or consulate, Honorary Consuls are appointed to further the bilateral relations between the host country and Malta, and to serve as a source of information for Maltese nationals. As Malta forms part of the Schengen area, there are additional arrangements with Italy and Austria for these States' diplomatic representations to issue Schengen visas on Malta's behalf in third countries where Malta does not have representation (CARE 2010).

Furthermore, under the 'EU Directive on consular protection for unrepresented European citizens living or travelling outside the EU' ${ }^{23}$ unrepresented EU citizens are entitled to receive consular protection under the same conditions as nationals of the consulate's country. Therefore, Maltese citizens or their family members who are in distress in a country without a Maltese embassy or consulate may seek help at the embassy of any other EU state in cases of arrest or detention; being victims of

\footnotetext{
${ }^{21}$ The Malta High Commission in London. Ministry for Foreign Affairs and Trade Promotion. https://foreignaffairs.gov.mt/en/embassies/hc_london/pages/services.aspx. Accessed 31 March 2019.

${ }^{22}$ Directorate for Consular Services. Ministry for Foreign Affairs and Trade Promotion. https:// foreignaffairs.gov.mt/en/Pages/Directorate-for-Consular-Services.aspx. Accessed 31 March 2019. ${ }^{23}$ Consular protection outside the EU. (2019, March 21). European Commission. https://ec.europa. eu/info/policies/justice-and-fundamental-rights/eu-citizenship/consular-protection_en. Accessed 31 March 2019.
} 
crime; serious accident or injury; death; relief and repatriation during emergencies; and whenever they need an emergency travel document.

Malta has an extensive number of double taxation treaties, which ensure that tax is never paid twice on the same income in different countries. ${ }^{24}$ Apart from this, as a small state Malta generally harnesses its human capital over limited material resources. Therefore, while the Maltese government offers a range of services to the Maltese diaspora through its representations, it does not provide cash benefits to nationals residing abroad in any circumstance. Moreover, Malta has no set practice of repatriation of corpses and no repatriation agreements. Thus, while the consular and embassy officials assist with logistical needs that arise when a Maltese citizen dies abroad - such as obtaining death certificates and putting next-of-kin into contact with a local undertaker - neither the Ministry for Foreign Affairs, nor the Ministry for Health, covers repatriation costs. It is not possible to provide funds for the funeral, nor to bring relatives of the deceased to the place where death has occurred, or to accompany the corpse back to Malta. Malta is not party to the 1973 Agreement on the Transfer of Corpses (CARE 2010). Repatriations of human remains are carried out according to International Regulations and under the supervision of Port Health Authorities. ${ }^{25}$

In addition to assistance with legal or health issues, education of said human capital is arguably prioritised, as evidenced by local and foreign governments offering scholarships for Maltese citizens who may wish to undertake their studies abroad. Following an official notification of an offered scholarship, the Scholarship Unit within the Directorate for Maltese Living Abroad issues a press release, distributes and receives applications from interested parties, coordinates interviews, and offers practical guidance to successful candidates.

Cultural diplomacy also falls within the remit of the MFTP. Through the Cultural Diplomacy Unit, established in 2013, Maltese Representations are responsible for the bilateral cultural agreements with other countries, as well as the promotion of Maltese culture and identity abroad. The CDU works with the Arts Council Malta the national agency for development and investment in the cultural and creative sectors - to promote the local culture overseas through the diplomatic missions. In 2012, the CDU launched the Cultural Diplomacy Fund to incentivise Maltese Missions abroad to organise and participate in cultural events. In addition to the CDU, the Fund is managed by an appointed board consisting of representatives from MFTP, Ministry for Justice, Culture and Local Councils, and the Ministry for Finance. $^{26}$

\footnotetext{
${ }^{24}$ Double Taxation Treaties. FinanceMalta. https://www.financemalta.org/double-taxation-agreements/. Accessed 31 March 2019.

${ }^{25}$ Repatriation of Human Remains. Health.gov.mt. https://deputyprimeminister.gov.mt/en/environmental/Health-Inspectorate/PHS/Pages/Repatriation-of-Human-Remains.aspx. Accessed 31 March 2019

${ }^{26}$ Directorate General Global Issues, International Development and Economic Affairs. Ministry for Foreign Affairs and Trade Promotion. https://foreignaffairs.gov.mt/en/Pages/DG-EEA.aspx. Accessed 31 March 2019.
} 
Complementing the work of the CDU are civil society groups, which seek to promote Maltese culture abroad; a prime example is the Maltese Culture Movement in the UK. This is a community organisation that organises traditional Maltese functions and events, and promotes Maltese talent in the UK. ${ }^{27}$ Civil society organisations like the Maltese Culture Movement are run on a philanthropic basis, and there is no specific Maltese policy by which citizens residing abroad receive incentives to create or run not-for-profit organizations, although one-off incentives may be provided.

The Council for Maltese Living Abroad Act (Chapter 515) embraces all that is considered in the promulgation and dissemination of local culture and education abroad. The duties of the CMLA include the maintenance and promotion of the cultural and linguistic identity of Maltese communities abroad, particularly the teaching of the Maltese language. ${ }^{28}$ An additional duty is to analyse and verify the problems encountered by Maltese Communities abroad, including professional and educational training and development, and recognition of qualifications and skills gained in Malta. ${ }^{29}$ In the UK, the Malta Diaspora UK (newly founded in 2020) also operates within the parameters of the CMLA and incorporates all Maltese entities in the UK for representation to the Maltese government.

Whilst these initiatives have bolstered support for the communities of Maltese abroad, there are still steps to be taken to ensure their full democratic participation. Residence in Malta is a requirement for the qualification of voters in all types of elections - local, national, European Parliament and national referenda. 'Residence' referred to in Article 57 of the Constitution does not mandate physical presence in Malta as it permits periodic absence for work, study, illness, or mission. Such residency is difficult to monitor in any case, however, owing to free movement between EU member states inherent to membership. In the past, it was possible to ascertain how long an individual had been out of Malta by checking travellers' mandatory embarkation and disembarkation cards, however these are no longer used.

At the same time, there is no system whereby Maltese citizens abroad can cast their votes externally. Although no rule expressly forbids expatriate citizens from voting, they must return to Malta to do so in person; the financial and logistical difficulties thereby disenfranchise those who cannot afford it. Since 2011, the European Commission has been taking Malta to task over this flagrant disenfranchisement. Successive Maltese governments have been lobbied and presented with petitions to allow Maltese citizens abroad to vote electronically, by post, or in person at Maltese representations. Over a thousand people signed a petition to this end ahead of the 2013 general election. However, any change to the electoral system requires an amendment to electoral laws. The government has yet to convene a Constitutional

\footnotetext{
${ }^{27}$ Aims of Movement. Maltese Culture Movement. https://www.malteseculturemovement. com/? $=4$. Accessed 31 March 2019.

${ }^{28}$ Chapter 515: Council for Maltese Living Abroad Act (2012, 22 July). Ministry for Justice, Culture and Local Government. http://www.justiceservices.gov.mt/DownloadDocument.aspx? app=lom\&itemid=11812\&l=1. Accessed 31 March 2019.

${ }^{29}$ Ibid.
} 
Convention to discuss the necessary constitutional reforms. Neither of the major political parties has made headway on this aspect, which may be attributable to a desire to maintain tighter control over the electorate.

The General Elections Act stipulates that Maltese citizens are permitted to vote in Malta 7 days before polling day, subject to taking an oath before the Electoral Commission (or anyone acting on its behalf, including consulates) that they will not be in Malta on the day of the election itself. Maltese citizens who are abroad for state representation or work purposes are offered the possibility of flying in to vote. In what has become common practice, the government offers a scheme by which eligible voters living abroad can purchase return flight tickets with the national airline, Air Malta, at a subsidised rate (DeBono 2013). DeBono (2013) highlights how expensive this is for the government: 3057 voters had benefited from the scheme in the 2008 national election, costing the country $€ 1,015,724$ million; in the 2009 European Parliament election, 1377 voters benefited and the cost was €442,000. ${ }^{30}$

To run in local or general elections in Malta, prospective candidates must reside in Malta for at least an aggregate of 6 months in the 18 months preceding the election. The exception to this rule is when citizens are resident abroad owing to state service outside the country, such as military, police or diplomatic service; in this instance, they are deemed 'ordinarily resident' in Malta (DeBono 2013). Legally, it is permissible to stand for European Parliament elections in Malta, even if one is living abroad. However, it is necessary to register in Malta first. There are no additional formalities to go through if standing for home elections while abroad. However, the cultural practice in Malta - a largely bipartisan country with the highest non-compulsory voter turnout in the world - is for contenders to stand with one of the major political parties, and a local presence is expected, despite not being a legal requirement.

\subsection{Diaspora Policies and Social Protection in Malta}

It is evident that engagement with diaspora is a comprehensive process, targeting aspects as diverse as culture, education, and security. A foremost concern, however, is undoubtedly access to adequate social protection. The National Insurance system in Malta forms the backbone of the national social security system. It is based on regular payments and a redistribution system that covers residents for benefits in sickness and maternity, retirement, invalidity and widows, injury and occupational diseases, unemployment, and family benefits. As a result of Malta's accession to the EU, social benefits became available to all citizens from other EU member states and, reciprocally, Maltese became eligible to benefits from other EU states. Additionally, the government of Malta has been very active in ensuring Maltese

\footnotetext{
${ }^{30}$ Twegiba ghall-mistoqsija parlamentari numru 13091. (2009, 23 November). House of Representatives Malta. www.pq.gov.mt. Accessed 31 March 2019.
} 
nationals abroad receive adequate social protection, manifested in the Reciprocal Agreements it has signed with third countries hosting Maltese emigrants, which generally cover health and unemployment benefits, industrial injuries, and contributory pensions for retirement and widows.

\subsubsection{Unemployment}

Due to the EU legislation, an unemployed individual who receives unemployment benefits in Malta can leave the country to search for work in another EU Member State, and continue to temporarily receive unemployment benefit. Beyond this provision, links are provided by MFTP to visit the European Employment Service (EURES) website for Malta. Maltese EURES advisers can answer questions related to moving, living and working conditions in any EURES Member State. The MFTP website also provides pre-departure information on 'Obtaining or Renewing Your Passport' and provides a list of Maltese representatives abroad to guide individuals looking for work abroad.

The Maltese government offers schemes to assist participants in developing the skills needed to integrate in the labour market. The Employment and Training Corporation (ETC) was renamed in 2016 to Jobsplus, ${ }^{31}$ a dynamic organisation that aims to meet the labour market needs of employers, jobseekers and employees. The primary functions of the ETC included the provision of a public employment service and the training of individuals to improve their skills to find employment. Malta's accession to the EU boosted the Corporation's financial resources by tapping into the European Social Fund to expand its employment and training services, and to facilitate the employment of disadvantaged and disabled persons and the training of employed persons by employers. Jobsplus now provides a range of training schemes, such as the Traineeship Scheme, the Work Exposure Scheme, the Work Placement Scheme, and the Youth Guarantee.

Jobsplus delivers training programmes locally, so these would not be available to persons living abroad and must be accessed prior to the move overseas. However, Maltese nationals living abroad can contact Jobsplus by email or phone. Issues related to social protection and conditions of work, however, do not fall within the remit of Jobsplus. Concerned individuals are directed, instead, to the aforementioned International Relations Unit within the Department of Social Security. Individuals may also access the Citizens First website run by Europa, the EU's portal. $^{32}$

Although the government of Malta website provides specific information on 'Searching and Applying for a Job Overseas', there are no pre-departure in-person

\footnotetext{
${ }^{31}$ History. Jobsplus. https://jobsplus.gov.mt/about/history. Accessed 31 March 2019.

${ }^{32}$ FAQ. Ministry for Foreign Affairs and Trade Promotion. https://foreignaffairs.gov.mt/en/Pages/ FAQ.aspx. Accessed 31 March 2019.
} 
training sessions for Maltese moving abroad for work. Consulates are unable to offer specific training or official assistance in the search for employment. Furthermore, nationals residing abroad are not entitled to cash benefits, in-kind benefits or repatriation assistance, in case of unemployment, from the consulates.

\subsubsection{Health Care}

Malta has a strong public healthcare system, which provides free healthcare services to all Maltese citizens and residents, including the Maltese diaspora. According to Subsidiary Legislation 35.28 Healthcare Fees Regulation, a citizen of a country which has a reciprocal health care agreement in force with Malta, or a person who enjoys freedom of movement in terms of article 44 of the Constitution of Malta, has free access to all state healthcare.

Malta follows EU regulation 883/04 and implementing regulation 987/09 on the coordination of social security systems, which includes offering reciprocal emergency healthcare treatment for EU citizens with a European Health Insurance Card (EHIC). The services provided to Maltese nationals by the Directorate for Consular Services at MFTP include medical assistance. The consulate and embassy officials' assistance, however, is limited to tending to logistical needs and liaising with local authorities and health institutions. Consulates may help Maltese nationals access home coverage abroad by submitting administrative documents, but do not offer direct access to health services on their premises, cash benefits or repatriation services. Moreover, Malta is part of the EU Directive 2011/24/EU on patients' rights in cross-border healthcare under which EU citizens have the right to access planned healthcare in any other Member State and be reimbursed by their home country.

Beyond EU regulations, Malta has signed bilateral healthcare agreements with other countries. The Bilateral Reciprocal Healthcare Agreement with Australia provides, free of charge, immediately necessary medical and public hospital care for residents during their first 6 months. Malta had also signed a Social Security Reciprocal Agreement with the UK as early as 1956, to assist citizens to move between the two countries, obtain their due benefits, and regulate the payment of social security contributions. This Agreement covers health benefits and allows Maltese and UK citizens to freely use the health services of each other's country if they can prove that they are ordinary residents.

The rise of online services is revolutionising the way the government can provide select services to its diaspora, including mental healthcare. The Ministry for the Family, Children's Rights and Social Solidarity funds a programme called 'kellimni. com', which is run in collaboration with the non-governmental organisation Solidarity Overseas Service Malta (SOS Malta). It is a child and adolescent online support service run by trained staff and volunteers. Through kellimni.com, youth can, in an anonymous way, express their concerns and talk about the issues directly affecting them. Kellimni.com is aimed at youths who are suffering from any form of social exclusion, abuse, neglect, or psychological difficulties, and who are in need 
of immediate emotional, moral, and social support. ${ }^{33}$ Although the service is not directly meant for the Maltese diaspora, the fact that it is online means that it is accessible from abroad too. This shows a form of deterritorialization of Malta's health policies.

\subsubsection{Pensions}

The Social Security Act (Cap. 318 of the Laws of Malta) regulates the social security system in Malta and provides for two basic schemes: the Contributory Scheme, and the Non-Contributory Scheme. In order to be entitled to the Contributory Scheme, persons employed, self-employed or not in receipt of a salary (whose income does not come from economic activity but from other sources) pay contributions on a weekly basis. Any person between the age of sixteen and retirement age is required to pay contributions. All cash benefits are administered by the Department of Social Security. These contributory pensions - retirement, invalidity and widows - are all exportable to all parts of the world, so long as the applicant qualifies and meets the contribution requirements.

Two methods of payment are available to beneficiaries of Maltese pensions residing inside and outside the EU: in SEPA countries (Single Euro Payments Area), payments are made directly by the Department of Social Security to the beneficiary every 4 weeks. With respect to the other countries, the payments are made through a bank transfer approximately twice a year, to cover a back payment of 6 months. Pensioners who do not live in a SEPA country are encouraged to open a bank account in Malta or in another SEPA country to receive their pension regularly every 4 weeks.

The Maltese consulates cannot provide cash benefits to Maltese pensioners living abroad as they are only administered by the Department of Social Security. Furthermore, there is no policy permitting consulates to submit documents on behalf of Maltese residents abroad. Every individual must apply personally for his or her pension, and applications are forwarded to Malta. Consulates may assist Maltese nationals by informing them of the process or directing them to the social security services in their country of residence, if they reside in an EU country. For third countries, the application must be lodged at the Department of Social Security in Malta by downloading the claim forms and sending them by post, or by lodging a claim physically whilst on holiday in Malta. ${ }^{34}$ Whilst consulates may help residents locate the Retirement or Widow/ers Pension application claim form online, it is the host country's government department that must ultimately forward the claim

\footnotetext{
${ }^{33}$ Kellimni.com. SOS Malta - Solidarity Overseas Service. http://www.sosmalta.org/kellimni. Accessed 31 March 2019.

${ }^{34}$ Pensions Information. Department of Social Security. https://socialsecurity.gov.mt/en/pensions/ Pages/default.aspx. Accessed 31 March 2019.
} 
forms to Malta. ${ }^{35}$ The consulates may also assist by issuing cheques to residents who cannot receive online bank transfers. When a pensioner dies, the family is required to inform the pension officer within the consulate, who will then inform the Department of Social Security in Malta. Life Certificates are sent once a year from Malta to all pensioners paid abroad, and failure to return it duly endorsed will result in the suspension of pension.

Regarding invalidity pensions, according to the Maltese Social Security Act an invalidity pension may be awarded to a person who is certified as being unfit for suitable full-time or part-time employment due to a serious disease or bodily or mental impairment, subject to the relative social security contribution conditions under the Social Security Act (Cap. 318.). The applicant must have been on sick leave and providing weekly sickness reports for the 6 months prior to the application for an invalidity pension (except in cases of terminal illness). ${ }^{36}$ Any person who satisfies the criteria and statutory conditions may lodge the application for the invalidity pension at the country of residence. Once awarded, the invalidity pension may be paid abroad, so long as all changes in circumstances are reported.

When moving between EU member states, under EU regulations there are two methods of apportioning responsibility for the payment of invalidity benefits; in Malta's case, responsibility is apportioned on a pro-rata basis. This occurs where the rate of benefit is determined by the length of the periods of insurance. Each state pays a rate of benefit which reflects the length of the claimant's insurance under their scheme. Benefits will be payable anywhere in the EU, EFTA, and Switzerland. A pro-rata invalidity pension is paid according to the same general proportionality rule applied for the old-age and survivor's pensions. ${ }^{37}$

Since Malta has signed Reciprocal Agreements with Australia, Canada, the UK, the Netherlands and New Zealand on a number of benefits, including retirement, invalidity and widow/ers' pensions, Maltese nationals residing in these countries should claim their Maltese pension by lodging a claim through the social security institution of the respective country. ${ }^{38}$ The Agreement with the UK was specifically revised in 1996 to further include invalidity benefits. Moreover, Maltese pensioners who receive a British pension and vice versa will not experience any change in their situation due to Brexit. The Agreement between Malta and the UK is the only Reciprocal Agreement that Malta has with a foreign country which deals with the payment of short-term benefits, in addition to the usual long-term benefits. ${ }^{39}$

\footnotetext{
${ }^{35}$ Retirement Pension Under the Social Security Agreement between Malta and Australia. Department of Social Security. https://socialsecurity.gov.mt/en/Documents/Benefits-andAssistance/RetirementPensionAUSEN.pdf. Accessed 31 March 2019.

${ }^{36}$ Benefits Covered. Department of Social Security. https://socialsecurity.gov.mt/en/InternationalAffairs/Pages/Benefit-Covered/Benefits-Covered.aspx. Accessed 31 March 2019.

${ }^{37}$ Ibid.

${ }^{38}$ Pensions Information. Department of Social Security. https://socialsecurity.gov.mt/en/pensions/ Pages/default.aspx. Accessed 31 March 2019.

${ }^{39}$ Convention on Social Security between the Government of the Republic of Malta and the Government of the United Kingdom of Great Britain and Northern Ireland. (1996, 1 September).
} 
A Reciprocal Agreement with Australia, signed in 1991, contends with retirement, widowhood, and invalidity; the non-contributory pensions and assistance are also covered in Malta. ${ }^{40}$ This agreement provides that, where necessary, any residence in Australia should be deemed periods of contributions in Malta and viceversa. On retirement pensions, the Department of Social Security must inform the applicant in writing about the outcome of the claim. Once awarded, the pension is deposited into a bank account as specified by the applicant on the application form. ${ }^{41}$ A contributory retirement pension is awarded with effect from the day following date of retirement.

In 1992 an Agreement was signed with Canada, covering contributory pensions in relation to retirement, widowhood and invalidity, and orphan and death benefits. ${ }^{42}$ The Malta-Canadian Reciprocal Agreement further regulates with respect to the payment of social security contributions in cases where a resident of one country is working in the other. Canada's social security system is based partly on residence periods and a financial means test. Canada exercises a dual role Social Security System where it has a contributory system and a residence-based old age pension system. Provisions are found where residence in one country becomes contributions in another, and vice-versa.

Further Reciprocal Agreements were signed with the Netherlands in 2001 and New Zealand in 2013. The benefits covered in the latter include pensions in respect of retirement and widowhood for Malta, and superannuation and veterans' pensions for New Zealand. In 1990, Malta signed a similar, albeit more limited, agreement with Libya, which stipulated that no Maltese worker would need to pay Social Security contributions whilst working in Libya. The Maltese Embassy in Tripoli left Libya in 2014 due to the violent clashes that broke out in the city between rival armed groups (Galea 2019). To date, the critical insecurity situation in Tripoli has prevented the re-opening of this Embassy.

\footnotetext{
Ministry for the Family, Children's Rights and Social Solidarity. https://socialsecurity.gov.mt/en/ about-us/Documents/Reciprocal\%20Agreemets/mt_uk.pdf. Accessed 31 March 2019.

${ }^{40}$ Agreement on Social Security between the Government of Australia and the Government of Malta. (1990, 15 August). Ministry for the Family, Children's Rights and Social Solidarity. https:// socialsecurity.gov.mt//en/about-us/documents/reciprocal\%20agreemets/mt_australia.pdf. Accessed 31 March 2019.

${ }^{41}$ Retirement Pension under the Social Security Agreement between Malta and Canada. Department of Social Security. https://socialsecurity.gov.mt/en/Documents/Benefits-and-Assistance/ RetirementPensionCANEN.pdf Accessed 31 March 2019.

${ }^{42}$ Agreement on Social Security between the Government of Canada and the Republic of Malta. (1991, 4 April). Ministry for the Family, Children's Rights and Social Solidarity. https://socialsecurity.gov.mt//en/about-us/documents/reciprocal\%20agreemets/mt_canada.pdf. Accessed 31 March 2019.
} 


\subsubsection{Family-Related Benefits}

Malta follows the EU Social Security Coordination Regulations No 883/2004 ${ }^{43}$ and $987 / 2009,{ }^{44}$ offering family benefits to EU nationals or third country nationals who reside and work in Malta. The International Relations Unit at the Ministry for the Family, Children's Rights and Social Solidarity only caters for contribution-based benefits; therefore, the person concerned should have worked and contributed towards the Maltese Social Security Scheme prior to claiming any contributory based benefit. Maltese living in another EU Member State can only access family benefits through the social security institution of their state of residence, while Maltese nationals residing in a third country are not entitled to access home-country birth grants. With respect to child benefits for workers' families, these are provided by the state of employment, even if the family lives in another Member State. If entitlement would otherwise arise in more than one Member State, the regulations contain priority rules to determine who has primary responsibility for paying. If the effect of these priority rules puts a lower rate of benefit in payment, the state with the higher rate must pay a supplement to make up the difference. .

Beyond family benefits, other service in this area concerns the possibility for Maltese nationals to order birth certificates online or through any of the Maltese consulates. Applications for registration of documents are processed and stored at the Public Registry in Malta. Although not obligatory, Maltese consulates may assist Maltese citizens who want to register a birth abroad with the Maltese government.

\subsubsection{Economic Hardship}

The government of Malta does not offer a guaranteed minimum resources scheme and, therefore, Maltese consulates provide limited assistance to nationals residing abroad in cases of economic hardship. Under Art 6 of Decision 95/553/EC, ${ }^{45}$ consulates in EU member states do not provide any cash or in-kind benefits in case of non-health related economic hardship. However, consulates may assist nationals

\footnotetext{
${ }^{43}$ Regulation 883/2004/EC on the coordination of social security systems. (2004, 29 April). Official Journal. https://eur-lex.europa.eu/legal-content/EN/TXT/PDF/?uri=CELEX:02004R0883-201301 08. Accessed 31 March 2019.

${ }^{44}$ Regulation 987/2009/EC laying down the procedure for implementing Regulation (EC) No $883 / 2004$ on the coordination of social security systems (2009, 16 September). Official Journal. https://eur-lex.europa.eu/LexUriServ/LexUriServ.do?uri=CONSLEG:2009R0987:20130108:EN: HTML. Accessed 31 March 2019.

${ }^{45}$ Decision 95/553/EC of the Representatives of the Governments of the Member States meeting within the Council of 19 December 1995 regarding protection for citizens of the European Union by diplomatic and consular representations (1995, 19 December). Official Journal. https://eur-lex. europa.eu/legal-content/EN/TXT/?uri=celex:41995D0553. Accessed 31 March 2019.
} 
residing abroad in accessing financial assistance from family members or friends. In such cases, the next-of-kin may deposit an equal amount of money necessary to offset costs in any of Malta's diplomatic missions or Head Office in advance. The recipient Malta Mission will inform the Malta Mission dealing with the case that the money has been deposited or that a guarantee by the next-of-kin has been submitted.

As previously noted, Malta has no set practice of repatriation and no repatriation agreements in place. In exceptional circumstances, and on a case -by -case basis, assistance can be offered to repatriate the Maltese citizen back to Malta with financial assistance from relatives or certain funds in Malta, such as the Community Chest Fund.

\subsection{Conclusions}

In the Maltese legal system, there is no domestic law granting the right to consular or diplomatic protection; however, Malta has incorporated the provisions of the Vienna Convention, and assistance is offered as a matter of practice based on respect for fundamental rights of the individual, which are enshrined in Maltese law. The needs of Maltese diaspora predominantly fall under the remit of the Directorate for Maltese Living Abroad within the Directorate-General for Political, EU Affairs and Maltese Abroad, which forms part of the structure of the Maltese Ministry for Foreign Affairs and Trade Promotion. In addition to serving as the focal point for information and assistance, the Directorate liaises annually with the nominated Council for Maltese Living Abroad to advise the Ministry. No particular policies to incentivize Maltese to return were identified, and there was no evident distinction between policies applied in Malta or regionally in Gozo. Cultural and educational programmes are enacted through the MFTP's Cultural Diplomacy Unit and civil society groups. Furthermore, Malta has held four local Conventions for Maltese Living Abroad since 1969. These structures leverage Malta's limited human capital to facilitate communication and consultation on policy, and the promotion of national identity.

The strength of historic ties with the destination countries of Maltese emigrants is mainly reflected in the number of Reciprocal Agreements signed between Malta and partner countries. The International Relations Unit in the Ministry for the Family, Children's Rights and Social Solidarity contends with all benefits under all bilateral and international agreements which the Department of Social Security has entered into. The Maltese government does not provide any cash benefits, birth grants, local job training or repatriation services for nationals residing abroad. Malta does have a strong public healthcare system, which provides free healthcare services to all Maltese citizens, including the Maltese diaspora. Where Malta does not have a Reciprocal Health Agreement with a partner country, however, the consulate and embassy officials' assistance is limited to tending to logistical needs and liaising with local authorities. Conforming with small state trends, human capital is leveraged and logistical assistance favoured over expending limited material 
resources. Fortunately, the rise of online services is revolutionizing the way the government can provide select services to its diaspora communities, including mental healthcare and access to job training.

Whilst these steps have been taken to support the communities of Maltese abroad, there are still essential steps to be taken to ensure their full democratic participation. This is because physical presence in Malta is a requirement for the qualification of voters in all types of elections. Although no rule expressly forbids expatriate citizens from voting, they must return to Malta at their own expense to do so in person; the financial and logistical difficulties thereby continue to disenfranchise those who cannot afford it, and the country bears unnecessary, hefty costs by subsidising flights during elections. This is a peculiarity of Malta because the majority of EU countries allow external voting through their representations, by postal vote or online, yet Maltese politicians have remained unwilling to cede to the petitions of their citizens living abroad. Where technology has enabled increasing deterritorialization of national health policies, it should be harnessed more fully by the Maltese to enfranchise their electorate, demonstrate trust in the democratic process, and to further fortify their engagement with diaspora through economical and concrete means.

Acknowledgements This chapter is part of the project "Migration and Transnational Social Protection in (Post)Crisis Europe (MiTSoPro)" that has received funding from the European Research Council (ERC) under the European Union's Horizon 2020 research and innovation programme (Grant agreement No. 680014). In addition to this chapter, readers can find a series of indicators comparing national social protection and diaspora policies across 40 countries on the following website: http://labos.ulg.ac.be/socialprotection/

\section{References}

Attard, L. E. (1989). The Great Exodus (1918-1939). Malta: Publishers Enterprises Group Ltd. http://www.maltamigration.com/history/exodus/chapter3-4.shtml?s=4E1675C4-7F0000017DA803104013-6891. Accessed 31 Mar 2019.

CARE Project. (2010). Consular and diplomatic protection: Legal framework in the EU Member States. Ittig-Cnr, University of Vienna, IISA. ISBN 978-88-905764-1-6.

Cauchi, M. N. (2016, August 23). The Maltese diaspora: Changing faces of Malta abroad. https:// mauricecauchi.wordpress.com/2016/07/16/the-maltese-diaspora-changing-faces-of-maltaabroad/. Accessed 31 Mar 2019.

DeBono, D. (2013, June). Access to Electoral Rights Malta. EUDO Citizenship Observatory. http://eudo-citizenship.eu/admin/?p=file\&appl=countryProfiles\&f=132-Malta-FRACIT.pdf. Accessed 31 Mar 2019.

Galea, A. (2019, January 13). Mere formality left before Carmelo Saliba takes up residency as Malta's ambassador to Libya - Abela. The Malta Independent. http://www.independent.com. mt/articles/2019-01-12/local-news/Mere-formality-left-before-Carmelo-Saliba-takes-upresidency-as-Malta-s-ambassador-to-Libya-Abela-6736201954. Accessed 31 Mar 2019.

Jones, H. R. (1973). Modern emigration from Malta. Transactions of the Institute of British Geographers, 60(60), 101-119. https://doi.org/10.2307/621508.

Saliba Haig, A. (2016, June 28). UK - Malta health and social security treaties. Chetcuti Cauchi Advocates Malta. https://www.ccmalta.com/publications/health-and-social-security- 
treaties?fb clid=IwAR2ZxgsrQg_2fpU7fHdpQ7GOwcg9AuX39jteNQw0oA9KeSho3MBelwwqw0. Accessed 31 Mar 2019.

Sansone, K. (2017, June 27). Maltese in UK will get special 'settled status'. Times of Malta. https://www.timesofmalta.com/articles/view/20170627/local/maltese-in-uk-will-get-specialsettled-status.651769. Accessed 31 Mar 2019.

Xerri, R. (2015, January 27). Intervention at the ETTW-EESC and Latvian Presidency Conference on 'Basic European Rights to Free Movement under Threat.'https://www.eesc.europa.eu/ resources/docs/raymondxerri.pdf. Accessed 31 Mar 2019.

Open Access This chapter is licensed under the terms of the Creative Commons Attribution 4.0 International License (http://creativecommons.org/licenses/by/4.0/), which permits use, sharing, adaptation, distribution and reproduction in any medium or format, as long as you give appropriate credit to the original author(s) and the source, provide a link to the Creative Commons license and indicate if changes were made.

The images or other third party material in this chapter are included in the chapter's Creative Commons license, unless indicated otherwise in a credit line to the material. If material is not included in the chapter's Creative Commons license and your intended use is not permitted by statutory regulation or exceeds the permitted use, you will need to obtain permission directly from the copyright holder.

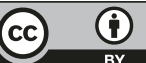

